\title{
Evaluation some important microbiological parameters of the carbon cycle in chernozem soils profiles
}

\author{
János Kátai - Zsolt Sándor - Magdolna Tállai - Ágnes Zsuposné Oláh \\ University of Debrecen, Faculty of Agricultural and Food Sciences and Environment Management, \\ Institute of Agrochemistry and Soil Science, Debrecen, Hungary \\ katai@agr.unideb.hu
}

\section{SUMMARY}

Some chemical and microbiological properties of the carbon cycle were investigated in three chernozem soil profiles. The soil profiles originated from a long term fertilization experiment (potato) of the University of Debrecen, Látókép, Kryvyi Rig Botanic Garden (grassland) and a large-scale farm (sunflower) of Ukraine. The results of the organic C-content, total number of bacteria, microscopical fungi, cellulose decomposing bacteria, $\mathrm{CO}_{2}$-production, microbial biomass carbon and saccharase and dehydrogenase activities were compared and evaluated with the help of correlation analyses. Close correlation was found between the organic carbon content and the number of microscopical fungi,, saccharase and dehydrogenase enzymes' activities, as well as close correlation was found between the dehydrogenase activity and microbial biomass-C and saccharase activity.

Keywords: chernozem soil, organic-C, soil microbes, $\mathrm{CO}_{2}$-production, microbial biomass carbon, saccharase enzyme's activity

\section{ÖSSZEFOGLALÁS}

A szénkörforgalom néhány kémiai és mikrobiológiai tulajdonságát vizsgáltuk három csernozjom talajprofiljában. A talajok a Debreceni Egyetem, látóképi trágyázási tartamkísérlet talajszelvényéböl (burgonya), a Krivij rig-i Botanikuskertböl (Ukrajna) gyep vegetáció alól és Krivij Rig közelében fekvö nagyüzemböl (napraforgó) származnak. A talajszelvények szerves C-tartalmát, az összes baktériumszámot, a mikroszkopikus gombák, a cellulózbontó baktériumok mennyiségét, valamint a CO -termelés, mikrobiális biomassza szén, a szacharáz és dehidrogenáz enzimaktivitások eredményeit hasonlitottuk össze és korreláció analizis segítségével értékeltük azokat. Szoros korrelációt találtak a szerves széntartalom, valamint a mikroszkopikus gombák mennyisége, a szacharáz, és a dehidrogenáz enzimek aktivitása között különkülön, illetve a szoros korrelációt találtunk a dehidrogenáz aktivitása, valamint mikrobiális biomassza-C és a szacharáz aktivitás között.

Kulcsszavak: csernozjom talaj, szerves-C, talaj mikroorganizmusok, $\mathrm{CO}_{2}$-produkció, mikrobiális biomassza szén, szacharáz enzimaktivitás

\section{INTRODUCTION}

The function of the soil carbon cycle has regional, as well as worldwide implications. For example, ecosystem productivity and stability relies to a large part on the activity of the soil microbial community, whose nutrients and energy are provided by mineralization of organic carbon compounds. Increases in soil organic matter levels result in the sequestering of excess carbon-dioxide into soil organic matter (soils are a net pool for carbon dioxide), whereas management of the soil ecosystem in a manner causing declines in colloidal soil organic matter or ecosystem productivity converts the ecosystem into a source of mineral carbon (Tate, 1995).

Agrotechnical parameters contribute to the sustainability and enhancement of soil fertility, and thus the proper quantity and good quality of yield. At the same time these parameters influence the physical and chemical properties of soil, as well as the occurrence and activity of soil microbes. A long-term experiment is especially adapted to evaluate the cumulative effect of recurrent treatments and the tendency of changes in soil.

According to certain scientists (Andrejuk, 1990; Kátai, 1997, 1999.) the effect of a moderate dose of fertilizer on the soil biological activity $\left(\mathrm{CO}_{2}\right.$ production, cellulose decomposing activity, and enzymes activity) was stimulating. The sensitive soil microbiological parameters (cellulose decomposing activity, phosphatase activity) were inhibited by large doses of fertilizers (Gulyás, 1985; Kátai, 2010).
Tillage temporarily aerates the soil and controls weeds, but year by year it destroys desirable soil structure and eventually reduces aeration. These changes occur because of accelerated organic matter decomposition and the formation of dense impermeable tillage pans (Donahue et al., 1983).

Several authors examine the effect of different kind of tillage on the physical, chemical and biological properties of soil belonging to different soil type. Availability of an element to plants and microorganisms is generally associated with organic matter content, microbial activity, and $\mathrm{pH}$. Soil biological factors that influence soil quality are reviewed. These include size and diversity of the microbial, micro- and macrofaunal biomass. The effect of tillage, crop residues and microbial activity on soil stability, the benefits of legumes in rotation schemes and green manures are considered (Elliot et al., 1996). Kandeler and Murer (1993) examined the effects of temporary grassland and conventional tillage on aggregate stability and soil microbial processes in a field trial in Austria. They stated firstly, that temporary grassland increases microbial biomass; secondly microorganisms produce enzymes, which mineralize organic compounds and aggregate stability increases due to the influence of microbial biomass, their activities and their by products. After ploughing grassland, both aggregate stability and soil microbial processes decreased rapidly. These results indicate that continuous vegetation and the activities of soil organisms are preconditions to maintain high aggregate stability. Grego et al., (1996) discussed the 
response of microorganisms, both in biomass and activity, to management practices and changes in natural environment. Their results confirm that different land use induces large changes in soil organic matter content in a short time period which has a strong influence on soil microbial biomass. The quantity of microbialbiomass could be important because of the characterization of the soil state, its quantity are measured by the fumigation and incubation methods with chloroform (Szili-Kovács and Tóth, 2006; Szili-Kovács and Elhottova, 2007). In the carbon-cycle the quantity of cellulose decomposing bacteria is also an important parameter (Zsuposné, 2007; Sándor et al., 2008), the occurrence of different carbon forms was measured in different soil types by Vágó et al. (2001).

This paper deals with the comparison of the more important soil parameters taking part in the carbon cycle. Three chernozem soil profiles were investigated; the profiles have similar development stages and exposure, these can be found in Hungary (Debrecen-Látókép) and Ukraine (Kryvyi Rig). This paper shows the relevant results.

\section{MATERIAL AND METHODS}

The first soil profile was from a fertilization experiment Debrecen-Látókép, the plant culture was potato. It was set up in the eastern part of hajdúsági löszhát, on calcareous chernozem [according to WRB 2006: Calcic Endofluvic Chernozem (Endosceletic)] 28 years ago, in 1983. The second profile originated from Kryvyi Rig National Botanical Garden from the Southern eastern part of Ukraine, the vegetation was natural grassland, and the third one was from a large scale farm in the same region with sunflower vegetation. The latter two soils were chernozem too. In this paper some physical, chemical and microbiological soil properties are presented in the different chernozem soil profiles.

Among the physical properties, the moisture content was measured by drying the soil at $105^{\circ} \mathrm{C}$, the silt and clay fractions were measured by settling method, the plasticity index was determined according to Arany. The $\mathrm{pH}$ of soil was measured in distilled water and $1 \mathrm{M}$ $\mathrm{KCl}$ according to Buzás (1988). The organic carbon and nitrogen contents (Tyurin cit. Filep, 1988), the AL soluble phosphorus and potassium contents (Egner et al., 1960) of soil were determined.
The total numbers of bacteria (bouillon agar) and fungi (PGA) were measured by plate dilution method (Szegi, 1979), the number cellulose decomposing bacteria were measured according to the method for ,, the most probable germ number" (Pochon and Tardieux, 1962). The $\mathrm{CO}_{2}$-production was measured $\left(\mathrm{CO}_{2} \mathrm{mg} 100 \mathrm{~g}^{-1} 7\right.$ days $^{-1}$ ) was measured by Jenkinson and Powlson (1976), the microbial biomass was measured by chloroform fumigation-extraction method according to the method Brookes (1985).

The measurement of saccharase activity carried out according to the method of Frankenberger et al., (1983). The dehydrogenase enzyme activity was measured by Mersi (1996), when the INT [2-(p-iodophenyl)-3(p-nitrophenil)-5-phenil tetrazolium chloride) reduced to INTF (iodonitro-tetrazolium formazan].

Soil samples were taken in 2010 in the three sampling place, the measurements were carried out in four repetitions, and the data were statistically evaluated by Microsoft Excel software.

\section{RESULTS AND DISCUSSION}

The results of eleven soil samples from three chernozem soil profiles will be shown partly in Table and partly in Figures. The first soil profile is from Debrecen-Látókép, Hungary, the second and third soil profiles are from Kryvyi Rig, Ukraine.

Comparing the soil profiles, the following can be stated:

1. the A and B-layers of Látókép profile are thicker and a $\mathrm{BC}$ transitional layer can be found there;

2. the Ukrainian soil profiles have a shallower fertile layers, the parent materials already begin from 60 $70 \mathrm{~cm}$;

3. the profiles 1 and 3 are under cultivation areas, the profile 2 is used as grassland more than ten years.

Among the physical properties the moisture content of 1 and 3 soil profiles was similar from the upper layer to the deeper ones the moisture content was higher than $20.0 \%$ (Table 1). There were very few differences among the moisture content of the different layers. But at the same time in the grassland (profile 2.) substantially lower moisture content was measured, especially in the upper layers.

Table 1.

The physical and chemical properties of the three soil profile

\begin{tabular}{|c|c|c|c|c|c|c|c|c|}
\hline $\begin{array}{c}\text { The three soil } \\
\text { profiles } \\
(\mathrm{cm})\end{array}$ & $\begin{array}{c}\text { Moisture } \\
\text { content } \\
(\%) \\
\end{array}$ & $\begin{array}{c}\text { Arany-type } \\
\text { plasticity } \\
\left(\mathrm{K}_{\mathrm{A}}\right) \\
\end{array}$ & $\begin{array}{c}\text { Silt and Clay } \\
\text { fraction } \\
(\%)\end{array}$ & $\mathrm{pH}_{\mathrm{H}_{2} \mathrm{O}}$ & $\mathrm{pH}_{\mathrm{KCl}}$ & $\begin{array}{c}\text { Organic } \\
\mathrm{C} \%\end{array}$ & $\begin{array}{c}\text { AL-soluble } \\
\mathrm{P}_{2} \mathrm{O}_{5} \\
\left(\mathrm{mg} \mathrm{kg}^{-1}\right) \\
\end{array}$ & $\begin{array}{c}\text { AL-soluble } \\
\mathrm{K}_{2} \mathrm{O} \\
\left(\mathrm{mg} \mathrm{kg}^{-1}\right) \\
\end{array}$ \\
\hline 1. 2-25 & 20.58 & 38 & 44.08 & 6.24 & 5.16 & 1.96 & 996 & 890 \\
\hline $25-40$ & 23.59 & 39 & 53.64 & 6.56 & 5.40 & 1.83 & 982 & 740 \\
\hline $45-80$ & 22.84 & 40 & 42.12 & 7.08 & 6.07 & 1.54 & 881 & 250 \\
\hline $80-105$ & 23.45 & 43 & 51.80 & 8.15 & 7.35 & 1.22 & 619 & 240 \\
\hline $105-160$ & 23.00 & 38 & 38.16 & 8.35 & 7.61 & 0.84 & 128 & 375 \\
\hline 2. $2-30$ & 13.74 & 42 & 59.60 & 6.68 & 5.62 & 2.07 & 21 & 265 \\
\hline $30-70$ & 14.85 & 43 & 61.52 & 7.05 & 6.21 & 1.12 & 28 & 215 \\
\hline$>70$ & 19.32 & 43 & 38.24 & 8.32 & 7.42 & 0.76 & 46 & 175 \\
\hline 3. $2-30$ & 21.83 & 44 & 66.40 & 7.30 & 6.30 & 2.07 & 71 & 320 \\
\hline $30-60$ & 22.06 & 43 & 60.12 & 7.35 & 6.05 & 1.81 & 16 & 213 \\
\hline $60-90$ & 22.13 & 45 & 48.20 & 8.36 & 7.40 & 0.94 & 42 & 175 \\
\hline
\end{tabular}


The plasticity index, the quantity of silt and clay fraction was also the important examined parameters. The Arany-type plasticity indexes were higher in the Ukrainian soils so they have higher water holding capacity too than the soils from Látókép. According to this parameter the soils had loam and clay loam texture.

The silt and clay content in the Ukrainian soils generally was $10-20 \%$ larger in the A and B soil layers than it was in the Látókép soils. Especially the silt and clay content of arable layer from Látókép soil was strikingly low. The results from the parent material of the three profiles were similar. Among the $\mathrm{K}_{\mathrm{A}}$ and silt+clay content of soil was medium correlation.

Among the chemical properties the $\mathrm{pH}$, the organic $\mathrm{C}$-content $\%$, the AL-soluble phosphorus and potassium content of soils can be found in the Table 1 .

There are differences among the $\mathrm{pH}$ of three soil profiles. While the $\mathrm{pH}$ of the upper $\mathrm{A}$ and $\mathrm{B}$ layers in profile 1 , and $0-30 \mathrm{~cm}$ of profile 2 are slightly acidic, the all soil $\mathrm{pH}$ in profile 3 is slightly alkaline. Generally with the increase of depth the $\mathrm{pH}$ increase in the soil layers, in the deeper layer these are above 8.00 containing significant quantity of $\mathrm{CaCO}_{3}$. The differences between the $\mathrm{pH}_{\mathrm{H}_{2} \mathrm{O}}$ and $\mathrm{pH}_{\mathrm{KCl}}$ in the upper layers in Látókép profiles can refer a remarkable hidden acidity.

Organic C-contents of the upper layers are near $1.96 \%$ in the three profile, in the Ukrainian soils it is a little bit higher, 2.06. The organic-C content decreases in linear with the increase of depth of soil profile. Along the correlation analyses the clay+silt content was medium correlation with organic- $\mathrm{C}$ content $(\mathrm{r}=0.61)$.

Regarding the AL-soluble phosphorus content of profiles, the profile 1 from Látókép contains a huge quantity of phosphorus till $80 \mathrm{~cm}$ depth; it decreases with the increase of depth, but it considerable in the $\mathrm{C}$-layer too. The phosphorus content of profile 2 and 3 is smaller by near one order in all layers. In the A layer of grassland less phosphorus was measured than in the cultivated soil. According to the evaluation of the phosphorus content, the Ukrainian soils are poor or very poor in phosphorus.

Tremendous potassium content was measured in the A and B soil layers of Látókép profile. In the Ukrainian soil about only one fourth of potassium was measured, than it was in the Hungarian soil. According to the evaluation of potassium content, the Ukrainian soil of grassland is poor in potassium, the soil from large scale farm is proper in potassium. Along the correlation analyses medium correlation was found between the AL-soluble $\mathrm{P}_{2} \mathrm{O}_{5}$ and $\mathrm{K}_{2} \mathrm{O}(\mathrm{r}=0.66)$.

Among the microbiological properties the number of total bacteria and microscopical fungi, the number of aerobic cellulose decomposing bacteria, the $\mathrm{CO}_{2}$ production, the microbial biomass- $\mathrm{C}$ and the saccharase and dehydrogenase enzymes' activities were investigated. The microbiological properties of the three profiles are shown in Figures.

Concerning the total bacteria, by far the highest bacteria number was measured in the A-layer of Látókép profile. In this profile the number of bacteria decreases drastically with the increase of depth. In both two Ukrainian soil profiles the largest number of total bacteria was measured in the B-layers (30-70 and 30 $60 \mathrm{~cm}$ ), in the profiles the total bacteria number was between 6-14 million. These results can be seen in Figure 1.

The highest number of microscopical fungi was measured in the "A" layers of the soil profiles, among the three soil profiles the most fungi was found in the grassland' soil. Its number drastically decreased with the increase of depth (Figure 2). The most common occurring genus was the Rhizopus, Mucor, Penicillium, Aspergillus, Trichoderma, Fusarium. The organic-C content was close correlation with the number of microscopical fungi $(r=0.74)$.

Figure 1: Number of total bacteria in the three soil profile

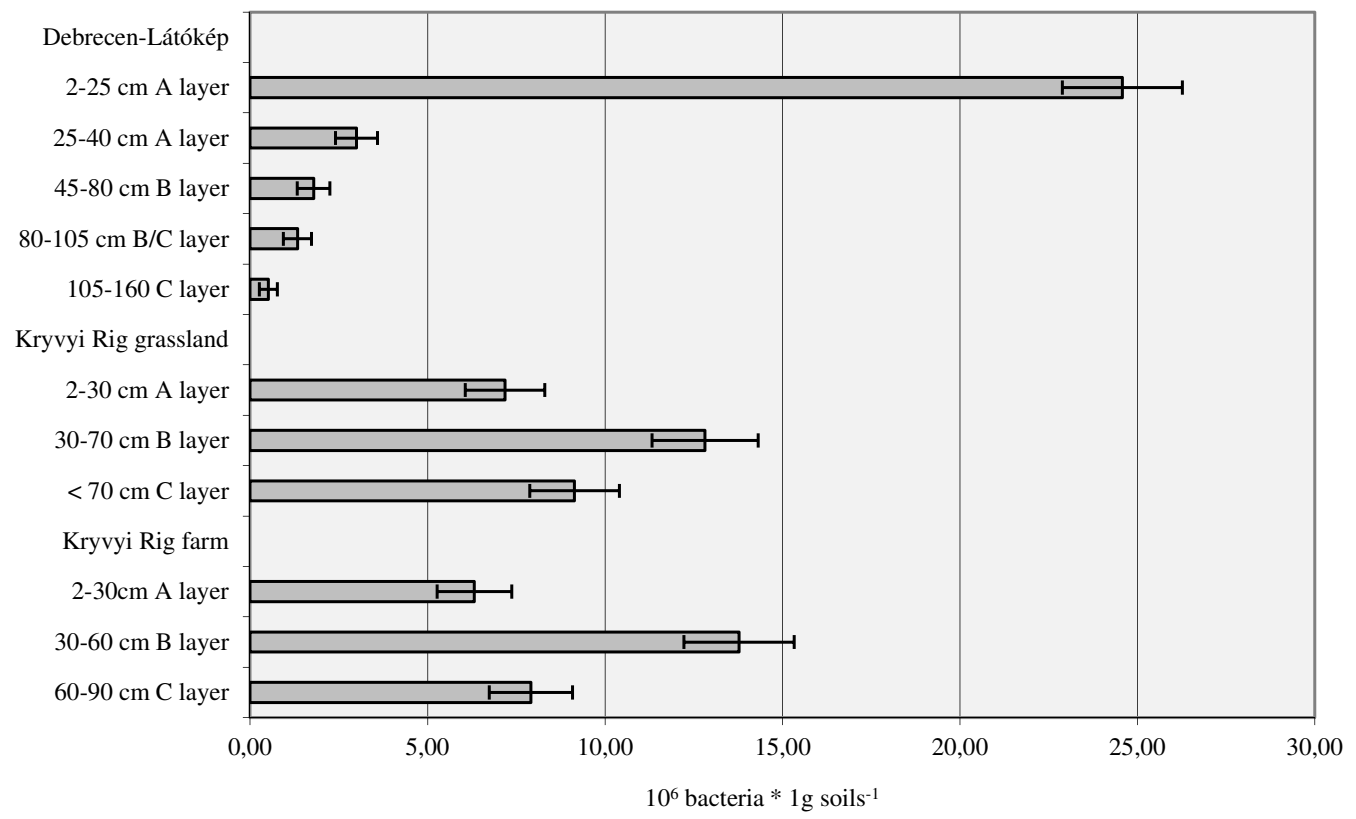


Figure 2: Number of microscopical fungi in the three soil profile

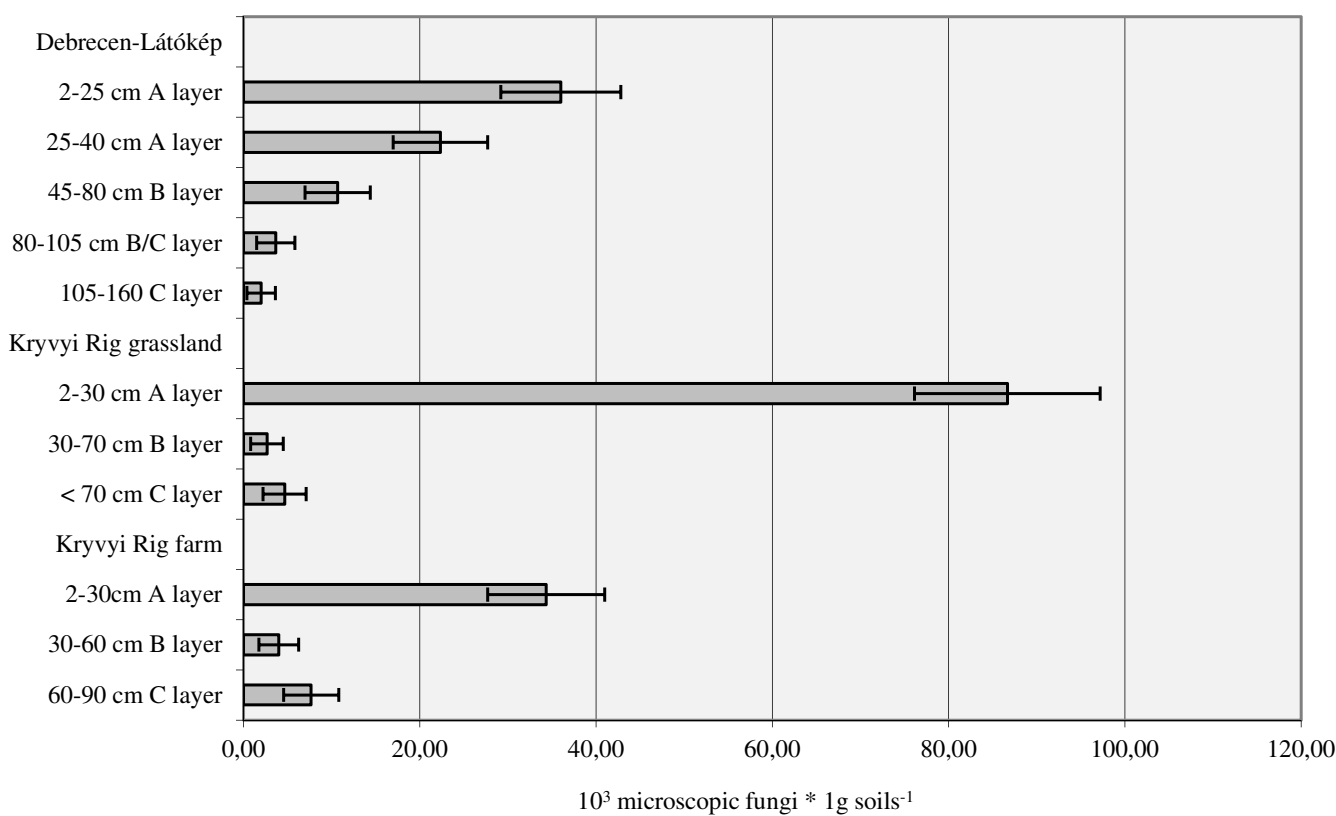

Among the important physiological groups of soil bacteria, the aerobic cellulose decomposing bacteria is one of the most important groups in connection with the carbon cycle. Generally the upper "A" layer contain the largest number of bacteria, except the grassland, where the "B" layer has the largest bacteria number. Its number gradually decreased with the increase of depth in the Látókép soil profile (Figure 3). Among the chemical soil properties only the AL-soluble $\mathrm{P}_{2} \mathrm{O}_{5}$ was medium correlation with the cellulose decomposing bacteria $(\mathrm{r}=0.59)$.

Among the soil profiles, the largest $\mathrm{CO}_{2}$-production was measured in the " $\mathrm{A}$ "-layers of fertilized Látókép profile, and it did not decrease drastically with the depth. In the Ukrainian grassland soil the $\mathrm{CO}_{2}$-productions were higher in the deeper layers where the moisture contents were higher too. In the profile of the large scale farm the highest quantity of $\mathrm{CO}_{2}$-production was measured in the "A"-layer (Figure 4).

Regarding the microbial biomass-carbon (MBC) similar results was measured in two soil profiles, in the upper " $\mathrm{A}$ " layer of the Látókép $\left(186.5 \mu \mathrm{g} \mathrm{g}^{-1}\right)$ and in the Ukrainian farm' profile $\left(185.2 \mu \mathrm{g} \mathrm{g}^{-1}\right)$, the highest quantity of it was measured in the " $A$ " layer of the Látókép soil. The microbial biomass-carbon decreased with the increase of the depth of all three profiles (Figure 5) Medium correlation was found between the $\mathrm{AL}-\mathrm{K}_{2} \mathrm{O}$ and $\mathrm{MBC}(\mathrm{r}=0.66)$, microscopical fungi and $\mathrm{MBC}(\mathrm{r}=0.62)$ as well as the $\mathrm{CO}_{2}$-production and $\mathrm{MBC}$ $(r=0.66)$. Close correlation was found between the organic carbon and the $\mathrm{MBC}(\mathrm{r}=0.80)$.

Figure 3: Number of aerobic cellulose decomposing bacteria in the three soil profile

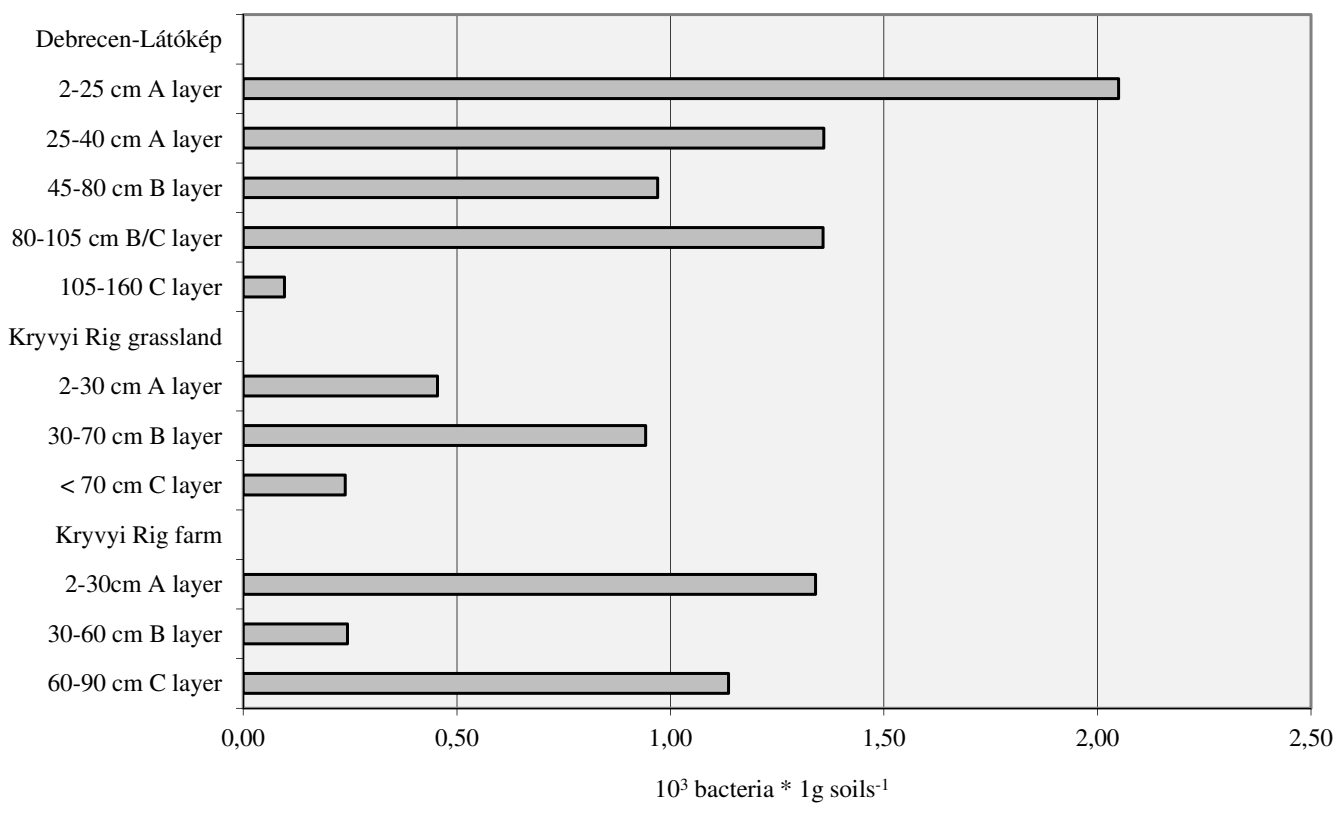


Figure 4: Quantity of $\mathbf{C O}_{2}$-production in the three soil profile

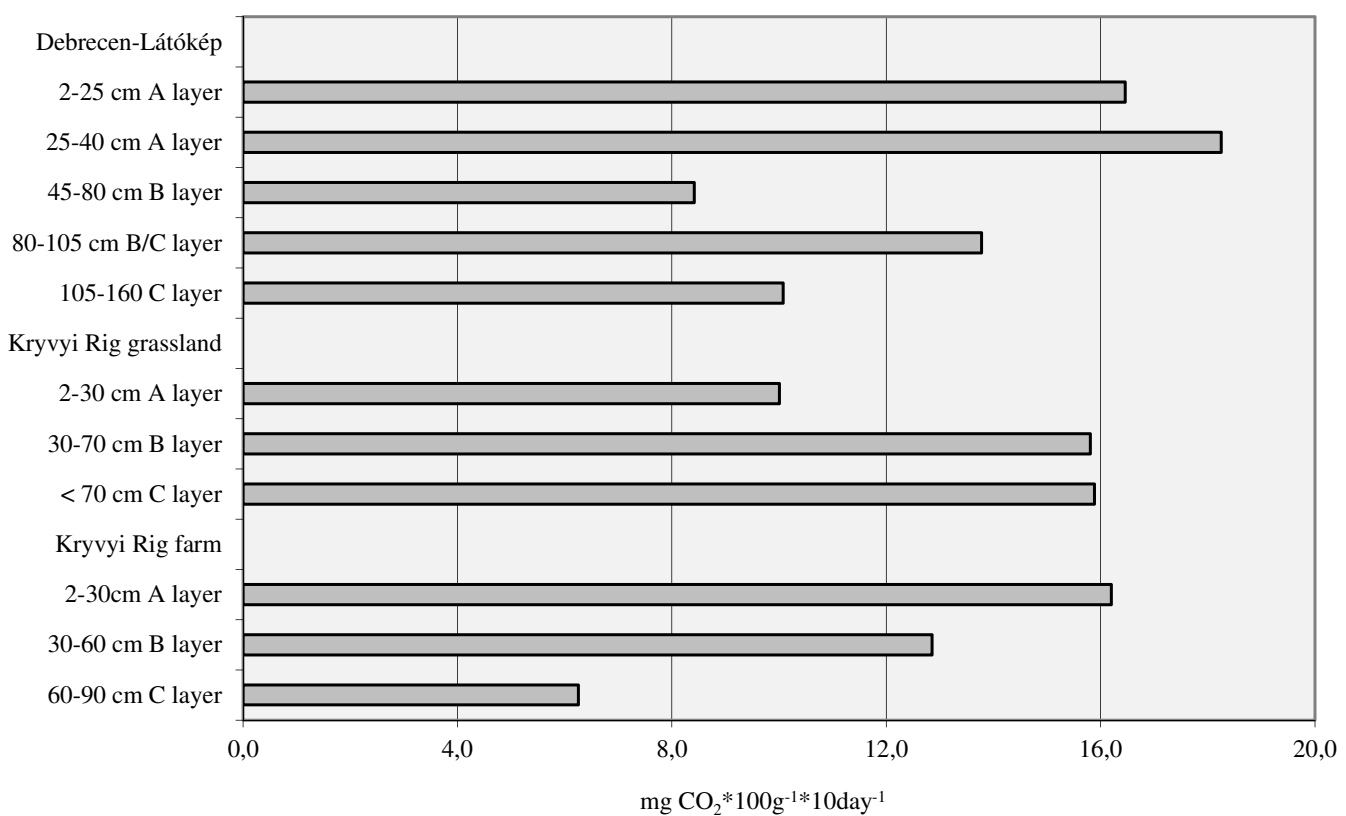

Figure 5: Quantity of microbial biomass-C in the three soil profile

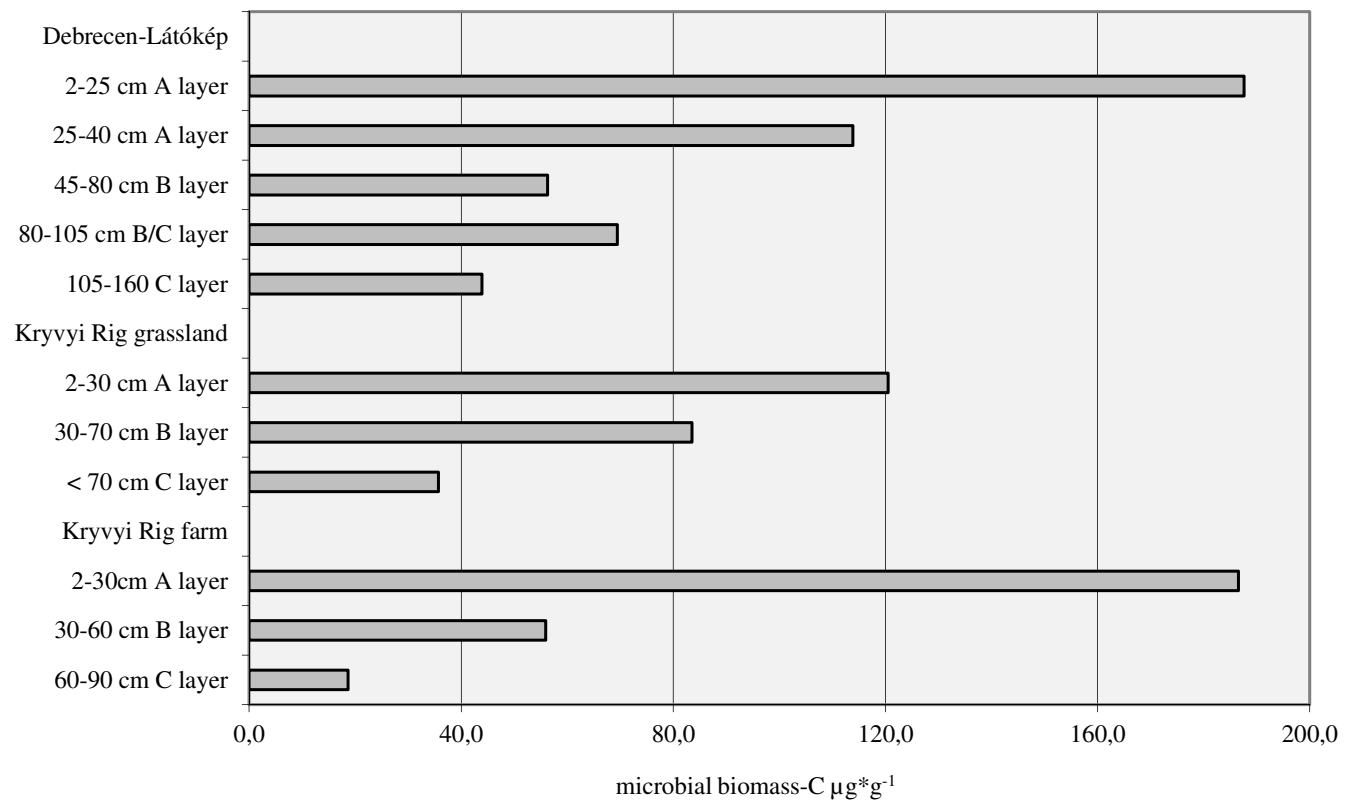

Regarding the saccharase enzyme' activity, higher activities were measured in the Ukrainian soils; this enzyme activity was higher by $20-30 \%$ than it was in the Látókép profile (Figure 0). Among the physical soil properties only the silt+clay content was medium correlation $(\mathrm{r}=0.52)$ with the saccharase activity. The organic carbon $(\mathrm{r}=0.62)$ content and microscopical fungi were medium correlation $(\mathrm{r}=0.60)$ with the saccharase activity, while the dehydrogenase activity was close correlation $(\mathrm{r}=0.83$ ) with sacchartase enzyme activity.

Although the dehydrogenase enzyme not a typical enzyme's of carbon cycle, we would like to show the results of this enzyme as it characterizes the total enzyme activity in the soil. In the activity of saccharase and dehydrogenase enzymes similar tendency was experienced. In the three soil profiles in the upper layers higher activities were measured, than in the deeper layers. Regarding this enzyme' activity, higher activities were measured in the Ukrainian soils, the dehydrogenase activities were near twice in the " $A$ " layer of Ukrainian soil profiles than it was in the Látókép soil profile. Along the correlation analyses the clay + silt content was medium correlation with dehydrogenase activity $(\mathrm{r}=0.62)$, while four parameters, so the organic carbon content $(\mathrm{r}=0.80)$, the number of microscopical fungi $(\mathrm{r}=$ $0.83)$, microbial biomass- $\mathrm{C}(\mathrm{r}=0.78)$ and the saccharase activity $(\mathrm{r}=0.84)$ were close correlation with the dehydrogenase activity (Figure 7). 
Figure 6: Activity of saccharase enzyme in the three soil profile

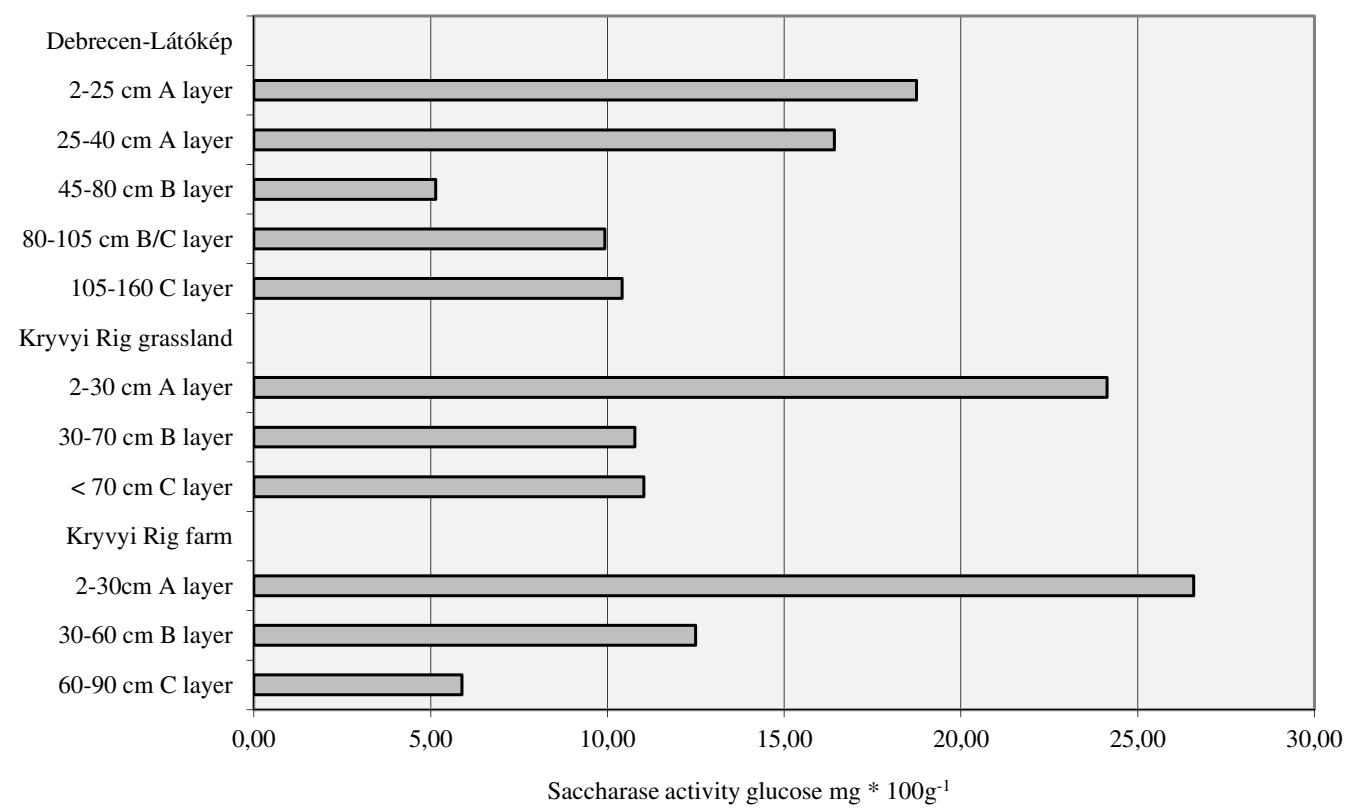

Figure 7: Activity of dehydrogenase enzyme in the three soil profile

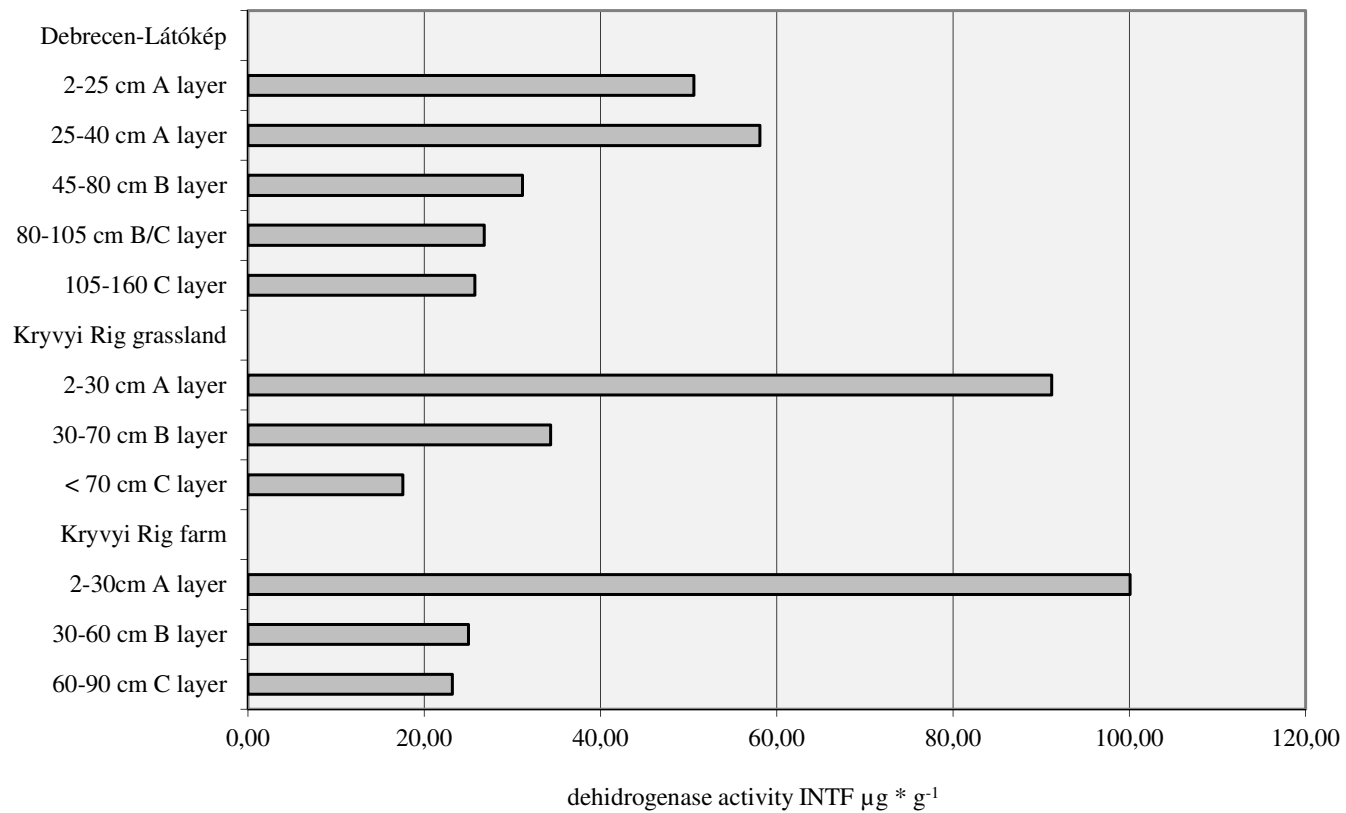

\section{CONCLUSIONS}

The physical, chemical and microbiological parameters of carbon cycle were evaluated from eleven soil samples originating from three chernozem soil profiles. The three chernozem soil profiles have similar development stages and exposure; these can be found in Hungary (Debrecen-Látókép) and Ukraine (Kryvyi Rig).

According to the plasticity index and silt+clay content the Hungarian soils belongs to the loam texture, while the Ukrainian soils were clay loam texture. The parent materials of the three profiles were similar loess.

While the $\mathrm{pH}$ of the upper A and B layers in Hungarian profile are slightly acidic, the soil $\mathrm{pH}$ in Ukrainian profile is slightly alkaline except the upper layer of grassland. Generally, with the increase of depth the $\mathrm{pH}$ in soil layers increase, in the deeper layer these are above 8.00 containing significant quantity of $\mathrm{CaCO}_{3}$.

Organic C-contents of the upper layers are near $1.96 \%$ in the three profile, in the Ukrainian soils it is $2 ., 06 \%$. With the increase of depth of soil profile, the organic-C content decreases in linear.

While the Hungarian profile contains a huge quantity of AL-soluble phosphorus till $80 \mathrm{~cm}$ depth, and potassium till $40 \mathrm{~cm}$, the phosphorus content of the two Ukrainian profiles is smaller by near one order in all layers. According to the evaluation of phosphorus content, the Ukrainian soils are very poor in phosphorus and medium scale applied in potassium.

Concerning the total bacteria and cellulose decomposing bacteria, by far the highest bacteria number was measured in the A-layer of Látókép profile. In both two Ukrainian 
soil profiles the largest number of total bacteria was measured in the B-layers.

The highest number of microscopical fungi was found in the A-layer of the grassland, but it drastically decreased with the increase of the depth of all profiles. The most common occurring genus was the Rhizopus, Mucor, Penicillium, Aspergillus, Trichoderma, Fusarium.

Regarding the activity of saccharase and dehydrogenase enzymes similar tendency can be experienced in the three soil profiles, in the upper layers higher activities were measured, than the deeper layers, higher activities were measured in the Ukrainian soils, while the saccharase activity was higher by $20-30 \%$, the dehydrogenase activity was near twice in the "A" layer of Ukrainian soil profiles.

Along the correlation analyses medium correlation was found among the measured parameters in several times, but close correlation was found between the organic carbon and the MBC $(r=0.80)$, as well as the organic carbon content, the number of microscopical fungi, the microbial biomass- $\mathrm{C}$ and the saccharase activity were close correlation with the dehydrogenase activity $(\mathrm{r}=0.80)$, $(\mathrm{r}=0.83),(\mathrm{r}=0.81)$ respectively.

Nevertheless the Látókép chernozem soil profile has proper physical properties; higher nutrient content in the all soil profile, and higher results in some parameters of the microbial dynamics (e.g. total number of bacteria), the Ukrainian soils seems to have larger total microbiological activity due to the higher organic carbon content and enzymes activities than the Hungarian soil profile.

\section{ACKNOWLEDGEMENTS}

This study was supported by Hungarian-Ukrainian Intergovernmental S\&T Cooperation Programme for 2009-2010" R\&D bilateral project "Change of soils ecological characteristics of Ukraine and Hungary in the conditions of anthropogenic transformed ecosystems and optimization of biological processes of plants primary feed elements mobilization."

\section{REFERENCES}

Andrejuk, E. I. (1990): Soil biotechnology and intensive agricultural production in soils of the Southern Ukraine. Agrokémia és Talajtan. 39. 3-4: 412-414.

Brookes, P. C. (1985): Chloroform fumigation and the release of soil nitrogen: A rapid direct extraction method to measure microbial biomass nitrogen in soil. Soil Biology and Biochemistry. 17: 837-842.

Buzás, I. (ed.) (1988): Methods of soil and agricultural chemisty analyses 2. Physical-chemical and chemical methods of soil analyses. Mezőgazdasági Kiadó. Budapest. 90-93.

Donahue, R. L.-Miller, R. W.-Shickluna, J. C. (1983): Soils. An introduction to soils and plant growth. Prentice-Hall Inc. Englewood Cliffs. New Jersey. 07632. 77-81.

Egner, H.-Riehm, H.-Domingo, W. R. (1960) Untersuchungen über die chemische Bodenanalyseals Grundlage für die Beurteilung de Nahrstoffzustandes der Böden. II. K. LantbrHögsk. Ann. 26 199-215.

Elliott, L. F.-Lynch, J. M.-Papendick, R. I.-Stotzky, G.-Bollag, J. M. (1996): The microbial component of soil quality. Soil Biochemistry. 9: 1-21.

Filep Gy. (1988): Talajvizsgálat. Egyetemi jegyzet. Debrecen. 105-107.

Frankenberger, W. T.-Johanson, J. B. (1983): Method of measuring invertase activity in soils. Plant and Soil. 74: 301-311.

Grego-Benedetti, A.-Dell-Orco, S.-Rossi, G.-Marinari, S.Badalucco, L. (1996): Agricultural practices and biological activity in soil. Fresenius-Environmental-Bulletin. 5-6: $282-288$.

Gulyás F. (1985): A foszfor- és káliumtrágyázás talajbiológiai hatásai. [In: Tóth B. (szerk.) A mezőgazdaság kemizálásának talajbiológiai kérdései.] MTA Veszprémi Akadémiai Bizottság Monográfiája. 33-52.

Jenkinson, D. S.-Powlson, D. S. (1976): The effect of biocidal treatments on metabolism in soil. A method for measuring soil biomass. Soil Biol. Biochem. 27. 8: 209-213..
Kandeler, E.-Murer, E. (1993): Aggregate stability and soil microbial processes in a soil with different cultivation. Geoderma 56. International Workshop. Wageningen.

Kátai, J. (1997): The effect of agrotechnical methods on microflora and biological activity in the soil. [In: Filep Gy. (ed.) Land Use and Soil Management.] 9-11. Dec. 1996. 240-252.

Kátai J. (1999): Talajmikrobiológiai jellemzők változása trágyázási tartamkísérletben. Agrokémia és Talajtan. 48. 3-4: 348-358.

Kátai, J. (2010): The influence of fertilization on the soil characteristics of a calcareous chernozem in a long term experiment. Journal of Agricultural Sciences. 38: 47-52.

Mersi, W. (1996): Dehydrogenase Activity with the Substrate INT. [In: Schinner, F. et al. Methods in soil biology.] Springer-Verlag Berlin-Heidelberg. 243-245.

Pochon, J.-Tardieux, P. (1962): Techniques D'analyse en microbiologie du sol. Collection "Technivues de Base". Editions de la Tourelle. St. Mandé.102.

Sándor, Zs.-Kátai, J.-Nagy, P. T. (2008): The effect of herbicides on some microbiological parameters of carbon-cycle in maize monoculture. Cereal Res. Commun. 36: 1175-1178.

Szegi, J. (1979): Methods for Soil Microbiological Analysis. Mezögazdasági Kiadó. Budapest. 49.

Szili-Kovács, T.-Elhottova, D. (2007): Substrate induced respiration in soils developed under stages of succession on a colliery heap. Cereal Res. Commun. 35. 2: 1169-1172.

Szili-Kovács T.-Tóth J. A.: (2006). A talaj mikrobiális biomassza meghatározása kloroform fumigációs módszerrel. Agrokémia és Talajtan. 55. 2: 515-530.

Tate, R. L. (1995): Soil Microbiology. Rutgers University. New Brunswick. New Jersey. 229-231.

Vágó I.-Kátai J.-Kiss Sz. (2001): Szén- és nitrogénformák előfordulása különbözö talajtípusokon. Innováció, a tudomány és a gyakorlat egysége az ezredforduló agráriumában. Gödöllő-Debrecen. 312-320.

Zsuposné Oláh, Á. (2007): Changes of biological activity in different soil types. Cereal Res. Commun. 35. 2: 861-864. 
